\title{
Openness and the effectiveness of monetary policy: empirical evidence from Turkey
}

\section{Hakan Berument \& Burak Doan}

To cite this article: Hakan Berument \& Burak Doan (2003) Openness and the effectiveness of monetary policy: empirical evidence from Turkey, Applied Economics Letters, 10:4, 217-221, DOI: $10.1080 / 1350485022000015842$

To link to this article: https://doi.org/10.1080/1350485022000015842

曲 Published online: 06 Oct 2010.

Submit your article to this journal $\pi$

Џ Article views: 84

Citing articles: 5 View citing articles 


\title{
Openness and the effectiveness of monetary policy: empirical evidence from Turkey
}

\author{
HAKAN BERUMENT and BURAK DOĞAN* \\ Department of Economics, Bilkent University, Ankara, Bilkent 06533, Turkey
}

The empirical evidence suggests that openness decreases the effect of monetary policy on output, however the effect on prices is not statistically significant. In this study these predictions are tested over the open economy of Turkey for quarterly data from 1987:1 to 2001:1. This study assesses how the openness affects the effectiveness of monetary policy on output and prices.

\section{INTRODUCTION}

In his paper Romer (1993) investigates the relationship between openness and inflation. He argues that the absence of precommitment in monetary policy leads to inefficiently high inflation. He claims that the less open economy would have a greater incentive to expand and so have a higher equilibrium of inflation rate. This relation can be explained as unanticipated monetary expansion causes real exchange rate depreciation and since more open economies are more available to be effected by the harms of real depreciation the benefits of unanticipated expansion are negatively correlated with the degree of openness. Therefore if the money authority considers openness as an important state variable for the monetary policy, monetary authorities in more open economies will on average expand money supply less and will have lower average rates of inflation. Dennis (2001) argues also that the well-known result of depreciation of domestic exchange rate is increasing inflation. But as Romer does, Dennis concludes that the money authority intervenes or does not lead to absence of precommitment in monetary policy. So expansion is less, and so inflation is lower in small open economies.

There is another point of view, which says that in a more open economy, increase of money supply is expected to be more inflationary while the change in the output level would be rather smaller than it is expected or negative. Because the ability of money to affect output is supposed to be weaker in more open economies, whereas the inflationary effects of changes in money supply increase with openness due to substitution effect. This differentiation is because of the different responses of the aggregate supplies of the both different countries by the mean of their openness levels. In an open economy the fluctuations of the exchange rates will create an expectation of depreciation of the currency. This expectation will trigger the wage demand so monetary expansion will be reflected on prices and less on output. Bryant et al. (1988), in their empirical study by more than 10 macroeconometric models, predict that monetary expansion raise output and the price level while the contractions have the opposite effects. Papadopoulos (1993) investigates the effects of monetary policy on output and prices for an open economy in the case of Greece for the period of 1955-1990. In his paper, he finds that contractionary government policy financed by domestic credit accelerated the recession with inflation declining after a two years lag. Atesoglu and Dutkowsky (1995) in their empirical study on money, output and prices in Turkey, mention that monetary expansion should not be involved with attempts to stimulate output. Karras (1999) confirms the same theory. In his paper Karras shows the expected theoretical effects of monetary policy empirically using a panel of 38 countries from the 1953-1990 periods. Karras argues that the effectiveness of the monetary policies is related to the openness of the economy such that the effect of expansionary monetary policy decreases output but increases the inflation rate. Guncavdi and

*Corresponding author. E-mail: bdogan@bilkent.edu.tr 
Kucukcifci (2001) in their paper which is about foreign trade and factor intensity also conclude that, the importation of intermediate goods created an employment generation and capital savings effects in 1990 in Turkey. They explain this fact by the general expectations of neoclassical theory of comparative advantage, which postulates that foreign trade induces the use of relatively abundant domestic resources as causing savings in scarce ones, such as capital.

The expectations can be summed up as follows; an unanticipated permanent monetary expansion raises aggregate demand. This is because of two reasons. First monetary expansion reduces the domestic interest rate and increases the aggregate demand. Second monetary expansion creates depreciation on domestic currency. As a result of depreciation on domestic currency, prices of domestic goods rise. In the short run output increases but in the long run following the adjustments of the monetary authority over the economy output declines backward.

This study assess that with the increasing degree of the openness, effectiveness of the monetary policy decreases on output and prices for more open economy in the case of Turkey. Quarterly data from 1987:1 up to 2001:1 period for Turkey is used to estimate the relationship between openness and the effects of monetary policy on output and prices. The estimated methods support the theoretical expectations: change in the money supply will lead to smaller output. Also as a parallel result of Romer's it was found out that expansionary monetary policy has an impact on inflation, which demonstrates a negative relationship with the level of openness.

The remainder of the paper consists of three sections. Section II sets out the specification used in this paper. Section III is the empirical results of the estimation and finally Section IV offers concluding remarks.

\section{EQUATIONS THAT ARE USED TO ESTIMATE}

In order to estimate the effect of openness on moneyoutput relationship the following equation is estimated:

$$
\begin{aligned}
\Delta y_{t}= & \beta_{0}+\sum_{i=1}^{3} \beta_{1} D_{i}+\beta_{2} \mathrm{D} 94_{t}+\sum_{i=1}^{4} \beta_{3 i} \Delta y_{t-i} \\
& +\sum_{i=0}^{4} \beta_{4 i} \Delta m_{t-i}+\sum_{i=0}^{4} \beta_{5 i}\left(\text { open }_{t-1} \Delta m_{t-i}\right)+u_{t}^{y}
\end{aligned}
$$

Here, $\Delta y_{t}$ is the output growth rate, $\Delta m_{t}$ is the money growth rate, open $t_{t}$ is the measure of openness at time $t$, $\beta$ s are the coefficients, $u_{t}^{y}$ is the output residual at time $t$. In order to assess the effect of the openness on money-price relationship the following equation is estimated:

$$
\begin{aligned}
\Delta p_{t}= & \alpha_{0}+\sum_{i=1}^{3} \alpha_{1} \mathrm{D}_{i}+\alpha_{2} \mathrm{D} 94_{t}+\sum_{i=1}^{4} \alpha_{3 i} \Delta p_{t-i} \\
& +\sum_{i=0}^{4} \alpha_{4 i} \Delta m_{t-i}+\sum_{i=0}^{4} \alpha_{5 i}\left(\text { open }_{t-1} \Delta m_{t-i}\right)+u_{t}^{p}
\end{aligned}
$$

Here $\Delta p_{t}$ is the inflation rate, $\Delta m_{t}$ is the money growth rate, open ${ }_{t}$ is the measure of openness at time $t, \alpha$ are the coefficients, $u_{t}^{p}$ is the output residual at time $t$.

Dummy variables with coefficient $\beta_{1}$ and $\alpha_{1}$ are used for the monthly effects for the quarterly data. Dummy variable D94 is used for the self-inflicted 1994 crisis at the second quarter.

The data for all the variables are gathered from the Central Bank of the Republic of Turkey electronic data delivery system. ${ }^{1}$ Real GDP growth rate is used for $\Delta y_{t}$, which is constant with 1987 prices. Logarithmic first difference of GDP deflator is used for inflation. Openness is quantified with two different fractions as being seasonally adjusted. One of the definitions of openness is the ratio of sum of the import and export with GDP both with 1987 prices [(IM+EX)/GDP]. The other definition is the ratio of import and GDP [IM/GDP]. In order to avoid simultaneity biased problem lag value of these ratios are entered into the specification. Three money aggregates; M1, M2, M2Y ${ }^{2}$ are used as the money indicators for $\Delta m$.

\section{EMPIRICAL RESULTS}

Table 1 reports the estimate of output equation (Equation 1) and Table 2 reports the estimate of price equation (Equation 2) for three money measures (M1, M2, M2Y). Tables are formed in two parts as 'Panel A' for the definition of openness as the ratio of sum of the import and export with GDP and 'Panel B' for the definition of open $_{t}$ as the ratio of import with GDP.

To be consistent with the theoretical expectations the estimated $\beta_{5 i}$ s that are the coefficients of the openness terms is expected to be negative to indicate the declining effects of money on output with openness. On the other hand, according to Karras's study estimated $\alpha_{5 i} \mathrm{~s}$ must be positive to indicate that prices increase by the increasing level of openness while it has to be negative to show a negative relationship between inflation and level of openness to fit with the Romer's expectations about the policy choice of money authority.

\footnotetext{
${ }^{1}$ http://tcmbf40.tcmb.gov.tr/cbt.html

${ }^{2} \mathrm{M} 2 \mathrm{Y}=\mathrm{M} 2+$ deposit in foreign currency denominated currency.
} 
Table 1. Output, money and openness ${ }^{\mathrm{a}}$

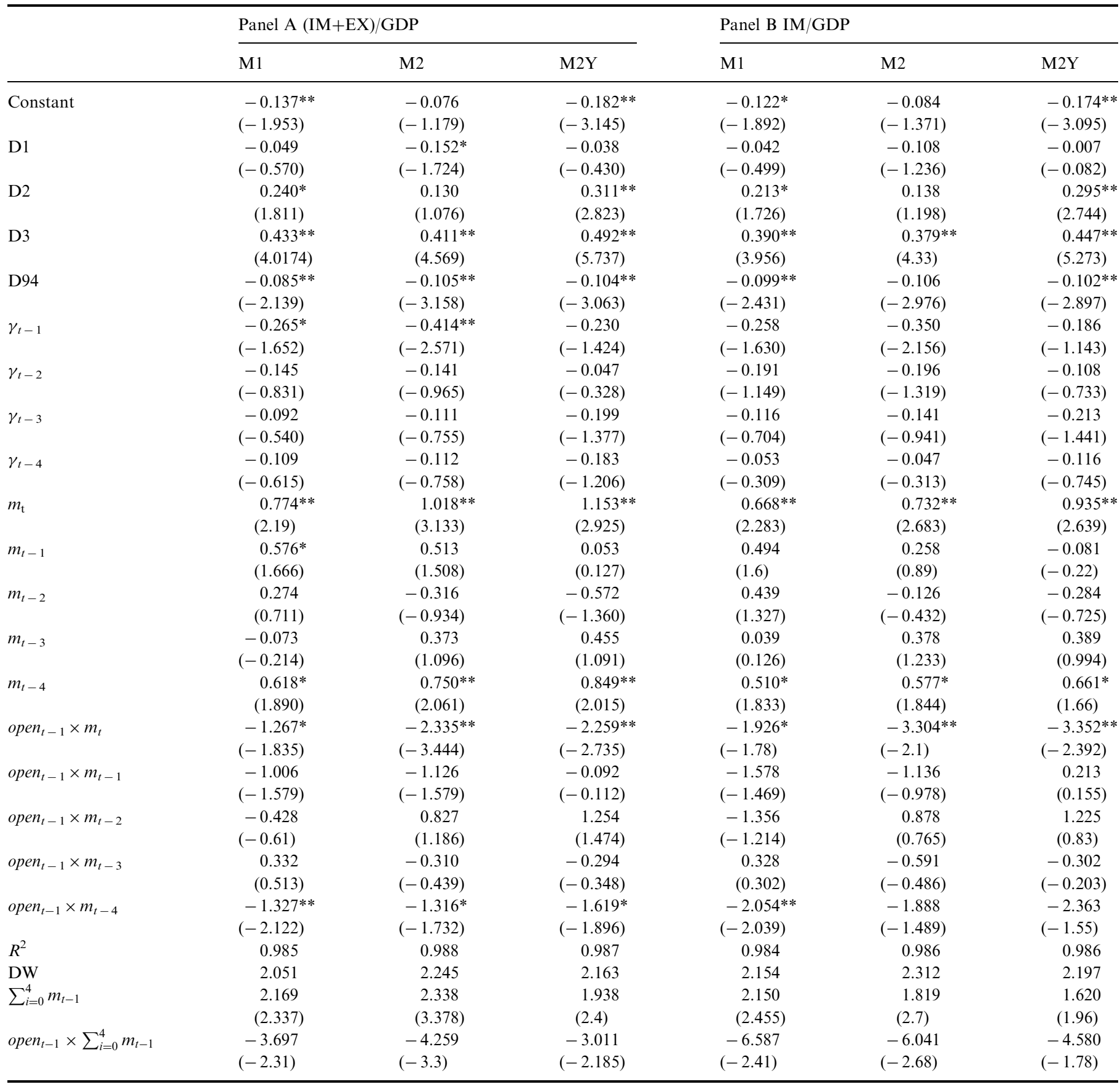

Note: ${ }^{\text {a }}$ The $t$-statistics are reported in parentheses; *Significant at $10 \%$; **Significant at $5 \%$.

Table 1 shows that for both definitions of openness and for all of the three definitions of money, the estimated coefficients of sum of the interactive term of money with openness, which is shown as open tr-1 $_{1} \times m_{t-i} \mathrm{~S}$ are negative and statistically significant. And also, even if the signs of estimated coefficients of $m_{t-i}$ s do change, the estimated coefficients of the sums of the $m_{t-i} \mathrm{~s}$ are positive and statistically significant. This suggests that, change in the money supply declines the level of output.

Table 2 shows that for both definitions of openness and for all of the three definitions of money, coefficients of the sums of the $m_{t-i} \mathrm{~s}$ are positive and statistically significant. And the coefficients of sums of the interactive terms are negative. This means that inflation decreases by the increasing level of openness. 
Table 2. Prices, money and openness

\begin{tabular}{|c|c|c|c|c|c|c|}
\hline & \multicolumn{3}{|c|}{ Panel A $(\mathrm{IM}+\mathrm{EX}) / \mathrm{GDP}$} & \multicolumn{3}{|c|}{ Panel B IM/GDP } \\
\hline & M1 & M2 & $\mathrm{M} 2 \mathrm{Y}$ & M1 & M2 & $\mathrm{M} 2 \mathrm{Y}$ \\
\hline \multirow[t]{2}{*}{ Constant } & $0.112 * *$ & 0.048 & $0.059^{* *}$ & $0.108^{* *}$ & 0.049 & $0.062 * *$ \\
\hline & $(3.245)$ & $(1.362)$ & $(2.171)$ & $(2.922)$ & $(1.362)$ & $(2.301)$ \\
\hline \multirow[t]{2}{*}{ D1 } & $0.037 * *$ & $0.054 * *$ & $0.040^{* *}$ & $0.038^{* *}$ & $0.053 * *$ & $0.036^{*}$ \\
\hline & $(2.123)$ & $(2.08)$ & $(2.123)$ & $(1.967)$ & $(1.99)$ & $(1.938)$ \\
\hline \multirow[t]{2}{*}{ D2 } & -0.007 & 0.011 & 0.008 & -0.003 & 0.012 & 0.004 \\
\hline & $(-0.333)$ & $(0.362)$ & $(0.353)$ & $(-0.138)$ & $(0.395)$ & $(0.163)$ \\
\hline \multirow[t]{2}{*}{ D3 } & $-0.054^{* *}$ & -0.040 & -0.015 & $-0.052^{* *}$ & -0.036 & -0.017 \\
\hline & $(-2.733)$ & $(-1.38)$ & $(-0.634)$ & $(-2.461)$ & $(-1.25)$ & $(-0.728)$ \\
\hline \multirow[t]{2}{*}{ D94 } & $0.188^{* * *}$ & $0.203^{* *}$ & $0.167 * *$ & $0.182^{* *}$ & $0.200^{* *}$ & $0.169^{* *}$ \\
\hline & $(5.713)$ & $(5.912)$ & $(5.854)$ & $(5.372)$ & $(5.795)$ & $(6.02)$ \\
\hline \multirow{2}{*}{$p_{t-1}$} & 0.065 & $0.310^{*}$ & $0.444^{* *}$ & 0.050 & $0.335^{* *}$ & $0.480^{* * *}$ \\
\hline & $(0.481)$ & $(1.895)$ & $(2.716)$ & $(0.338)$ & $(2.049)$ & $(2.944)$ \\
\hline \multirow[t]{2}{*}{$p_{t-2}$} & 0.210 & -0.101 & -0.287 & 0.172 & -0.155 & -0.308 \\
\hline & $(1.555)$ & $(-0.501)$ & $(-1.452)$ & $(1.147)$ & $(-0.787)$ & $(-1.555)$ \\
\hline \multirow[t]{2}{*}{$p_{t-3}$} & 0.168 & 0.509 & $0.418^{* *}$ & 0.152 & $0.491^{* *}$ & $0.404^{* *}$ \\
\hline & (1.219) & $(2.48)$ & $(2.233)$ & $(1.061)$ & $(2.518)$ & $(2.152)$ \\
\hline \multirow[t]{2}{*}{$p_{t-4}$} & $-0.248^{*}$ & -0.143 & -0.044 & -0.171 & -0.107 & -0.048 \\
\hline & $(-1.872)$ & $(-0.83)$ & $(-0.313)$ & $(-1.346)$ & $(-0.642)$ & $(-0.347)$ \\
\hline \multirow[t]{2}{*}{$m_{t}$} & -0.121 & -0.703 & $-1.230^{* *}$ & -0.193 & $-0.652^{* *}$ & $-1.232^{* *}$ \\
\hline & $(-0.413)$ & $(-2.136)$ & $(-3.804)$ & $(-0.732)$ & $(-2.401)$ & $(-4.231)$ \\
\hline \multirow[t]{2}{*}{$m_{t-1}$} & 0.267 & 0.073 & $0.891 * *$ & 0.203 & 0.139 & $0.889^{* *}$ \\
\hline & (0.909) & $(0.242)$ & $(2.522)$ & $(0.735)$ & $(0.539)$ & $(2.774)$ \\
\hline \multirow[t]{2}{*}{$m_{t-2}$} & $0.826^{* *}$ & 0.489 & -0.221 & $0.666^{* *}$ & 0.329 & -0.276 \\
\hline & $(2.886)$ & $(1.405)$ & $(-0.453)$ & $(2.427)$ & (1.123) & $(-0.603)$ \\
\hline \multirow[t]{2}{*}{$m_{t-3}$} & 0.229 & $0.165^{* *}$ & 0.509 & 0.183 & 0.185 & 0.440 \\
\hline & $(0.808)$ & $(0.422)$ & (1.194) & $(0.633)$ & $(0.556)$ & (1.108) \\
\hline \multirow[t]{2}{*}{$m_{t-4}$} & -0.262 & -0.242 & 0.032 & -0.092 & -0.163 & 0.077 \\
\hline & $(-0.94)$ & $(-0.613)$ & $(0.082)$ & $(-0.34)$ & $(-0.493)$ & $(0.215)$ \\
\hline \multirow[t]{2}{*}{ open $_{t-1} \times m_{t}$} & -0.277 & $0.679 * *$ & $1.131 *$ & -0.272 & 1.029 & $2.153^{* *}$ \\
\hline & $(-0.505)$ & $(0.983)$ & $(1.769)$ & $(-0.294)$ & $(0.968)$ & $(2.06)$ \\
\hline \multirow{2}{*}{ open $_{t-1} \times m_{t-1}$} & -0.344 & 0.426 & -0.591 & -0.385 & 0.681 & -1.042 \\
\hline & $(-0.637)$ & $(0.724)$ & $(-1.05)$ & $(-0.404)$ & $(0.714)$ & $(-1.129)$ \\
\hline \multirow[t]{2}{*}{ open $_{t-1} \times m_{t-2}$} & $-1.658^{* *}$ & $-1.462^{* *}$ & -0.482 & $-2.530^{* *}$ & $-2.234 * *$ & -0.735 \\
\hline & $(-3.234)$ & $(-2.32)$ & $(-0.656)$ & $(-2.798)$ & $(-2.253)$ & $(-0.592)$ \\
\hline \multirow[t]{2}{*}{ open $_{t-1} \times m_{t-3}$} & -0.363 & 0.046 & -0.417 & -0.539 & 0.001 & -0.486 \\
\hline & $(-0.681)$ & $(0.065)$ & $(-0.60-5)$ & $(-0.528)$ & $(0.0007)$ & $(-0.414)$ \\
\hline \multirow[t]{2}{*}{ open $_{t-1} \times m_{t-4}$} & 0.235 & 0.296 & -0.406 & -0.086 & 0.318 & -0.967 \\
\hline & $(0.445)$ & $(0.372)$ & $(-0.562)$ & $(-0.089)$ & $(0.245)$ & $(-0.785)$ \\
\hline$R^{2}$ & 0.902 & 0.873 & 0.912 & 0.896 & 0.873 & 0.914 \\
\hline \multirow{3}{*}{$\begin{array}{l}\text { DW } \\
\sum_{i=0}^{4} m_{t-1}\end{array}$} & 2.022 & 2.012 & 1.302 & 1.868 & 2.020 & 1.290 \\
\hline & 0.940 & -0.217 & -0.019 & 0.768 & -0.162 & -0.101 \\
\hline & $(1.09)$ & $(-0.28)$ & 1.31 & $(0.84)$ & $(-0.22)$ & $(-0.147)$ \\
\hline \multirow{2}{*}{ open $_{t-1} \times \sum_{i=0}^{4} m_{t-1}$} & -2.406 & -0.014 & -0.766 & -3.810 & -0.206 & -1.077 \\
\hline & $(-1.5)$ & $(-0.01)$ & $(-0.63)$ & $(-1.22)$ & $(-0.082)$ & $(0.5)$ \\
\hline
\end{tabular}

Note: See note to Table 1.

We can offer two explanations for this. First as being parallel to the view of Romer's, Turkish monetary authority injects money to system to maintain the current level of inflation (Turkey in her more than 25 years of high inflation did not experience hyperinflation) and injection of money just stimulate the output not inflation. Second, the openness measure increases due to higher imports. Higher imports, increases output and decreases prices due to substitution effect.

\section{CONCLUSIONS}

In this paper it is shown that openness is an important factor for the effectiveness of monetary policy. 
Theoretically, using an open-economy model, openness can be shown to reduce the ability of the monetary policy to affect output, while adversely effecting inflation. Using quarterly data from 1987:1 up to $2001: 1$ period for Turkey, it is empirically shown that output level and prices have negative relationship with the level of openness. Turkey is in a trend to open its economy to foreign trade. This would be good for the increment of the investments and money circulation. But as a result of this empirical study, it can be said that the effectiveness of the monetary policy declines to manipulate the output so as well as the control of the economy.

In the light of the economic literature and experiences of Turkish economy, level of openness must be kept in view for the choice of monetary policy. Here it was found out that, level of openness is negatively related to the average inflation rate. This means that Turkish money authority acts parallel to the predictions of Romer about the openness and monetary policy. But if money authority allows monetary expansion, it would cause Karras's predictions to come true and increase inflation. It is right that Turkey never experienced hyperinflation but also could not decreased high inflation for decades. So, Turkish money authority must be very careful when it is deciding for monetary expansion in the open economy conditions.

\section{REFERENCES}

Atesoglu, H. S. and Dutkowsky, D. H. (1995) Money, output and prices in Turkey, Applied Economics Letters, 2, 38-41.

Bryant, R., Henderson, D., Holtham, G. P. and Symansky, S. (1988) Empirical Macro Economics for Independent Economies, Brookings Institution, Washington, DC.

Dennis, R. (2001) Monetary policy and exchange rates in small open economies, FRBSF Economic Letter, 16(May), 1-4.

Guncavdi, O. and Kucukcifci, S. (2001) Foreign trade and factor intensity in an open developing country: an input-output analysis for Turkey, Russian and East European Finance and Trade, 37(1), 75-88.

Karras, G. (1999) Openness and the effects of monetary policy, Journal of International Money and Finance, 18, 13-26.

Papadopoulos, A. P. (1993) The effects of monetary, fiscal and exchange rate policies on output, prices and the balance of payments in the open economy of Greece: 1955-90, Applied Economics, 25, 879-90.

Romer, D. (1993) Openness and inflation: theory and evidence, Quarterly Journal of Economics, CVIII(November), 869-903. 